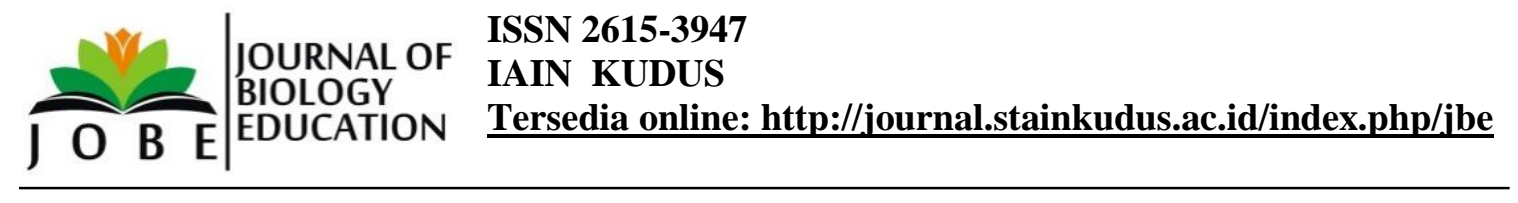

\title{
Pengaruh Motivasi Belajar Terhadap Prestasi Belajar Siswa Melalui Penggunaan Model Pembelajaran Teams-Games-Tournaments (TGT) Pada Mata Pelajaran Biologi Kelas X di MA NU 03 Sunan Katong Kaliwungu Kendal
}

\author{
Khosi'in \\ IAIN Bengkulu \\ khosi'in88@iainbengkulu.ac.id
}

\begin{abstract}
ABSTRAK
Penelitian ini membahas tentang pengaruh motivasi belajar dengan model pembelajaran Kooperatif Teams-Games tournament (TGT) terhadap prestasi belajar peserta didik kelas X mata pelajaran biologi materi pokok kingdom animalia. Tujuannya untuk mengetahui adakah pengaruh yang positif antara motivasi belajar dengan model pembelajaran Kooperatif TeamsGames tournament (TGT) dengan prestasi belajar peserta didik.

Metode angket dengan teknik korelasi yang digunakan untuk mengetahui motivasi belajar siswa, baik itu siswa kelas kontrol maupun kelas eksperimen. Adapun untuk mengetahui prestasi belajar peserta didik menggunakan hasil test sub bab materi pokok kingdom animalia. Pengumpulan data menggunakan instrumen angket dengan jumlah responden kelas eksperimen (XB) 35 siswa, sedangkan jumlah peserta didik kelas kontrol (XA) berjumlah 34 siswa, dengan menggunakan teknik random sampling.

Data yang terkumpul dianalisis dengan statistik menggunakan reumus regresi. Dari dua variabel yang ada yaitu, variabel X (motivasi belajar siswa dengan model pembelajaran TGT), pada kelas eksperimen memiliki rata-rata 53,571 itu lebih besar daripada rata motivasi belajar kelas kontrol $(39,056)$. Begitu juga rata nilai ulangan sub bab meteri kelas eksperimen lebih besar daripada kelas kontrol $(73,89>67,65)$.

Setelah diuji hipotresis ternyata terdapat pengaruh yang positif antara keadaan motivasi belajar dengan model pembelajaran Kooperatif Teams-Games-Tournament (TGT), hal ini ditunjukkan dengan $F_{\text {reg }}$ hitung : 15,544> $F_{1}$ tabel $5 \%(4,13), F_{\text {reg }}$ hitung : 15,544> $F_{1}$ tabel $1 \%(7,44)$. Dengan demikian hipotesis yang diajukan peneliti diterima dikarenakan terdapat pengaruh positif yang signifikan antara motivasi belajar dengan model pembelajaran Kooperatif Teams-Games-Tournament (TGT) terhada prestasi belajar peserta didik kelas X mata pelajaran biologi materi pokok kingdim animalia MA NU 03 Sunan Katong Kaliwungu Kendal..
\end{abstract}

Kata kunci: Motivasi belajar, prestasi belajar, model pembelajaran, teams games tournaments 


\section{PENDAHULUAN}

Dalam proses belajar mengajar siswa berperan sebagai subjek dan sekaligus objek dari kegiatan pembelajaran. Oleh karena itu inti dari proses pembelajaran tidak lain adalah kegiatan belajar siswa dalam mencapai tujuan akhir pembelajaran. Tujuan pembelajaran tentu saja akan tercapai jika guru melaksanakan kegiatan belajar mengajar melalui model pembelajaran yang mengaktifkan peran siswa dalam proses pembelajaran, sehingga siswa dapat meningkatkan hasil belajar atau prestasi belajarnya.

Proses belajar mengajar merupakan kegiatan interaksi antara guru-siswa dan komunikasi timbal balik yang berlangsung dalam situasi edukatif untuk mencapai tujuan belajar. Interaksi dan komunikasi timbal balik antara guru dan peserta didik merupakan ciri dan syarat utama berlangsunya proses belajar mengajar. Dalam kaitannya dengan proses belajar mengajar, agar proses ini dapat berjalan dengan maksimal dan tujuan pembelajaran dapat tercapai dengan baik, maka tuntutan pertama bagi guru adalah menguasai materi yang akan dipelajari murid. Dalam menyampaikan mata pelajaran peran guru sangat berpengaruh terhadap murid. Kita seringkali mendengar dari guru yang menceritakan bahwa banyak murid yang tidak tertarik mengikuti pelajaran dengan alasan merasa bosan dan ngantuk. Sebenarnya tidak ada pelajaran yang membosankan, yang benar adalah guru yang belum mengerti cara menyajikan materi yang benar, baik, menyenangkan dan menarik serta perhatian murid sehingga menyebabkan mata pelajaran tersebut membosankan bagi peserta didik.

Guru seharusnya tidak hanya mengandalkan verbalisme. Yang mana penyakit verbalisme terdapat dalam setiap situasi belajar, yakni apabila peserta didik diberi kata-kata tanpa memahaminya. Dalam proses belajar mengajar, para siswa perlu dilatih untuk bekerja sama dengan rekan-rekan sebayanya. Ada kegiatan belajar tertentu yang akan lebih berhasil jika dikerjakan secara bersama-sama, misalnya dalam kerja kelompok, daripada jika dikerjakan sendirian oleh masing-masing siswa. Latihan kerja sama sangatlah penting dalam proses pembentukan kepribadian anak.

Motivasi dapat dikatakan sebagai keseluruhan daya penggerak di dalam diri siswa yang menjamin kelangsungan dan memberikan arah kegiatan belajar, sehingga tujuan pembelajaran dapat tercapai. Sudah sangat jelas bahwa motivasi berfungsi untuk mendorong manusia untuk berbuat, menentukan arah perbuatan untuk mencapai tujuan dan menyeleksi perbuatan yakni perbuatan mana yang akan dikerjakan.

Pemeliharaan motivasi belajar itu dapat dilakukan dengan memanfaatkan model pembelajaran kooperatif, karena model pembelajaran kooperatif merupakan komponen yang cukup penting dalam strategi pembelajaran untuk melatih peserta didik supaya kooperatif, dapat bertanya meskipun tidak pada guru secara langsung, mengemukakan pendapat, serta memiliki kesan terhadap materi dan mampu mengaplikasikan teori di dunia nyata. 
Pembelajaran kooperatif adalah suatu model pembelajaran dimana siswa belajar dan bekerja dalam kelompok-kelompok kecil secara kolaboratif yang anggotanya 4-6 orang dengan struktur kelompok heterogen. Sedangkan model pembelajaran Teams-GamesTournaments (TGT) adalah salah satu tipe pembelajaran kooperatif yang menempetkan siswa dalam kelompok-kelompok belajar yang beranggotakan 5 sampai 6 orang siswa yang memiliki kemampuan, jenis kelamin dan suku kata atau ras yang berbeda.

Selain itu model pembelajaran TGT (teams-games-tournament) dapat diartikan juga suatu tehnik pembelajaran yang sama sperti STAD kecuali satu hal: TGT menggunakan turnamen akademik, dan menggunakan kui-kuis dan sitem skor kemajuan individu, dimana para peserta didik berlomba sebagai wakil tim mereka dengan anggota lain yang kinerja akademik sebelumnya setara seperti mereka. Oleh sebab itu sebelum mengadakan proses belajar mengajar seorang guru harus menentukan model pembelajaran yang tepat yang sesuai dengan tujuan pembelajaran.

\section{Motivasi Belajar}

Kata "motif", diartikan sebagai daya upaya yang mendorong sesorang untuk melakukan sesuatu. Motif dapat dikatakan sebagai daya penggerak dari dalam dan di dalam subjek untuk melakukan aktivitas-aktivitas tertentu demi mencapai suatu tujuan. Bahkan motif dapat diartikan sebagai suatu kondisi intern (kesiapsiagaan). Berawal dari kata "motif" itu, maka motivasi dapat diartikan sebagai daya penggerak yang telah menjadi aktif. Motif menjadi aktif pada saat-saat tertentu, terutama bila kebutuhan untuk mencapai tujuan sangat dirasakan/mendesak.

Menurut J. W. Atkinson, motivation is that the term has no fixed meaning in contemporary psychology. Motivation is defined as the complex forces, drives, needs, tension states, or other mechanisms that start and maintaint voluntary activity toward the achievement of personal goal. Sementara Gates dan kawan-kawan mengemukakan bahwa motivasi adalah suatu kondisis fisiologis dan psikologis yang terdapat dalam diri seseorang yang mengatur tindakannya dengan cara tertentu. Adapun Greenberg menyebutkan bahwa motivasi adalah proses membangkitkan, mengarahkan, dan memantapkan perilaku arah suatu tujuan.

Hakikat dari motivasi belajar adalah dorongan internal dan eksternal pada peserta didik yang sedang belajar untuk mengadakan perubahan perilaku. Motivasi belajar adalah

proses yang memberi semangat belajar, arah, dan kegigihan perilaku. Artinya, perilaku yang termotivasi adalah perilaku yang penuh energi, terarah dan bertahan lama. Motivasi merupakan salah satu factor yang turut menentukan keefektifan dan keberhasilan dalam pembelajaran, karena peserta didik akan belajar dengan sungguh-sungguh apabila memiliki motivasi belajar tinggi. 
a. Indikator Motivasi Belajar

Indikator motivasi belajar menurut Hamzah B. Uno dapat diklasifikasikan sebagai berikut:

1) Adanya hasrat dan keinginan berhasil.

2) Adanya dorongan dan kebutuhan dalam belajar.

3) Adanya harapan dan cita-cita masa depan.

4) Adanya penghargaan dalam belajar.

5) Adanya kegiatan yang menarik dalam belajar

6) Adanya lingkungan belajar yang kondusif sehingga memungkinkan pesrta didik dapat belajar dengan baik.

b. Fungsi Motivasi Dalam Belajar

Hasil belajar akan menjadi optimal, kalau ada motivasi. Makin tepat motivasi yang diberikan, akan makin berhasil pula pelajaran itu. Jadi motivasi akan senantiasa menentukan intensitas usaha belajar bagi para belajar. Sehubungan dengan hal itu ada tiga fungsi motivasi:

1) Mendorong manusia untuk berbuat, jadi sebagai penggerak atau motor yang melepaskan energi. Motivasi dalam hal ini merupakan motor penggerak dari setiap kegiatan yang akan dikerjakan.

2) Menentukan arah perbuatan, yakni ke arah tujuan yang hendak dicapai. Dengan demikian motivasi dapat memberikan arah dan kegiatan yang harus dikerjakan sesuai dengan rumusan tujuan.

3) Menyeleksi perbuatan, yakni menentukan perbuatan-perbuatan apa yang harus dikerjakan serasi guna mencapai tujuan, dengan menyisihkan perbuatanperbuatan yang tidak bermanfaat bagi tujuan tersebut.

c. Bentuk-Bentuk Motivasi Di Sekolah

Di dalam kegiatan belajar-mengajar peranan motivasi baik intrinsik maupun ekstrinsik sangat diperlukan. Motivasi bagi pelajar dapat mengembangkan aktivitas dan inisiatif, dapat mengarahkan dan memelihara ketekunan dalam melakukan kegiatan belajar.

Ada beberapa bentuk dan cara untuk menumbuhkan motivasi dalam kegiatan belajar di sekolah, di antaranya yaitu:

1) Memberi angka

Angka dalam hal ini sebagai simbol dari nilai kegiatan belajarnya. Banyak siswa belajar, yang utama justru untuk mencapai angka atau nilai yang baik. Sehingga siswa biasanya yang dikejar adalah nilai ulangan atau nilai-nilai pada rapot angkanya baik-baik. Angka-angka yang baik itu bagi para siswa merupakan motivasi yang sangat kuat. 
2) Hadiah

Hadiah dapat juga dikatakan sebagai motivasi, tetapi tidak selalu demikian. Karena hadiah untuk suatu pekerjaan, mungkin tidak akan menarik bagi seseorang yang tidak senang dan tidak berbakat untuk suatu pekerjaan tersebut.

3) Saingan/kompetisi

Saingan atau kompetisi dapat digunakan sebagai alat motivasi untuk mendorong siswa untuk belajar. Persaingan, baik persaingan individual maupun persaingan kelompok dapat mmeningkatkan prestasi belajar para peserta didik.

4) Mengetahui hasil

Dengan mengetahui hasil pekerjaan, apalagi kalau terjadi kemajuan, akan mendorong siswa untuk belajar lebih giat lagi. Semakin mengetahui bahwa grafik hasil belajar meningkat, maka ada motivasi untuk terus belajar, dengan suatu harapan hasilnya terus meningkat.

5) Pujian

Apabila ada siswa yang sukses atau berhasil menyelesaikan tugas dengan baik, perlu diberikan pujian. Pujian ini adalah bentuk reinforcement yang positif dan sekaligus merupakan motivasi yang baik. Oleh karena itu supaya pujian ini merupakan motivasi, pemberiannya harus tetap. Dengan pujian yang tepat akan memupuk suasana yang menyenangkan dan mepertinggi gairah belajar serta sekaligus akan membangkitkan harga diri.

6) Memberi ulangan

Para siswa akan giat belajar kalau mengetahui akan ada ulangan. Oleh karena itu memberi ulangan ini juga merupakan sarana motivasi. Tetapi yang harus diingat oleh guru, adalah yang terlalu sering melakukan ulangan (misalnya setiap hari) karena bisa membosankan para peserta didik.

Selain itu terdapat bentuk-bentuk motivasi yang lain seperti di bawah ini:

1) Teguran

Menegur berarti mengingatkan bila seseorang tidak mencapai standar agar dia dapat mencoba kembali mencapai standar tersebut. Di dalam menegur, seorang motivator harus dapat memperlihatkan kesalahan apa yang terjadi, memiliki cukup fakta dan disertai perasaan sang motivator, apakah marah, tersinggung ataupun frustasi. Mengkritik adalah sebuah tindakan yang sulit kalau kita melihat prinsip-prinsip berkomunikasi yang diungkapkan oleh Dale Carnegie, yaitu jangan mengkritik, mencerca atau mengeluh sebaliknya berikan penghargaan yang jujur dan tulus. Jadi sebisa mungkin jangan menyampaikan kritik, tetapi berikan saran-saran berharga yang membangun.

2) Amarah

Amarah adalah emosi yang digunakan oleh pembicara-pembicara untuk memukau pendengarnya. Amarah seorang jenderal digunakan untuk 
membangkitkan kemarahan seluruh tentaranya untuk membangkitkan semangat juang seluruh tentaranya. Begitu juga dengan amarah dari pengajar dapat meningkatkan minat belajar dari peserta didiknya.

3) Tantangan

Adalah target yang tidak mustahil untuk dilakukan dengan melihat keterbatasanketerbatasan yang ada. Tantangan yang realistis mampu membangkitkan antuasisme dari peserta didik untuk memberikan performa terbaik yang semakin baik lagi.

d. Faktor-faktor yang Mempengaruhi Motivasi Belajar

Menurut dimyati dan mudjiono, faktor-faktor yang mempengaruhi motivasi belajar adalah sebagai berikut:

1) Cita-cita atau aspirasi siswa

Motivasi belajar tampak pada keinginan anak sejak kecil. Keberhasilan mencapai keinginan dapat menumbuhkan kemauan bergiat yang akan menimbulkan citacita dalam kehidupan. Cita-cita dapat memperkuat motivasi intrinsik dan ekstrinsik.

2) Kemauan siswa

Keinginana seorang anak perlu dibarengi dengan kemampuan untuk mencapainya, karena kemauan akan memperkuat motivasi anak untuk melaksanakan tugas-tugas perkembangan.

3) Kondisi siswa

Kondisi siswa yang meliputi kondisi jasmani dan rohani mempengaruhi motivasi belajar.

4) Kondisi lingkungan siswa

Siswa dapat terpengaruh oleh lingkungan sekitar, oleh karena itu kondisi lingkungan sekolah yang sehat, kerukunan, dan ketertiban pergaulan perlu di pertinggi mutunya agar semangat dan motivasi belajar siswa mudah diperkuat.

5) Unsur-unsur dinamis dalam belajar dan pembelajaran

Siswa memiliki perasaan, perhatian, kemauan, ingatab, dan pikiran yang mengalami perubahan berkat pengalaman hidup.

\section{Model Pembelajaran Teams-Games-Tournaments (TGT)}

a. Pengertian TGT

Secara umum TGT sama saja dengan STAD kecuali satu hal: TGT menggunakan turnamen akademik, dan menggunakan kuis-kuis dan sistem skor kemajuan individu, di mana para siswa berlomba-lomba sebagai wakil tim meraka dengan anggota tim lain yang kinerja akademik sebelumnya setara seperti mereka. TGT sangat sering digunakan dengan STAD, dengan menambahkan turnamen tertentu pada struktur STAD yang biasanya. 
Dalam TGT peserta didik memainkan permainan-permainan dengan anggota tim lain untuk memperoleh skor bagi tim mereka masing-masing. Penyusunan permainan dapat disusun dalam bentuk kuis berupa pertanyaan yang berkaitan dengan materi pelajaran.

Model Pembelajaran Kooperatif tipe Teams-Games-tournament (TGT), atau pertandingan permainan tim dikembangkang secara asli oleh David De Vries dan Keath Edward (1995). Pada model ini siswa memainkan permainan dengan anggotaanggota tim lain untuk memperoleh tambahan poin untuk skor tim mereka.

b. Komponen TGT

1) Presentasi Kelas (Penyajian Kelas)

Sama seperti dalam STAD, yaitu: Materi dalam TGT pertama-tama diperkenalkan dalam presentasi di dalam kelas. Ini merupakan pengajaran langsung seperti yang sering kali dilakukan atau diskusi pelajaran yang dipimpin oleh guru, tetapi bisa juga memasukkan presentasi Audiovisual. Bedanya presentasi kelas dengan pengajaran biasa hanyalah bahwa presentasi tersebut haruslah benar-benar berfokus pada TGT. Dengan cara ini, para siswa akan menyadari bahwa mereka harus benar-benar memberi perhatian penuh selama presentasi kelas, karena dengan demikian akan sangat membantu mereka mengerjakan kuis-kuis/game-game, dan skor kuis mereka menentukan skor tim mereka.

2) Kelompok (tim)

Tim terdiri dari empat atau lima siswa yang mewakili seluruh bagian dari kelas dalam hal kinerja akademik, jenis kelamin, ras dan etnistas. Fungsi utama dari tim ini adalah memastikan bahwa semua anggota tim benar-benar belajar, dan lebih khususnya lagi, adalah untuk mempersiapkan anggotanya untuk bisa mengerjakan kuis dengan baik.

3) Game

Gamenya terdiri atas pertanyaan-pertanyaan yang kontennya relevan yang dirancang untuk menguji pengetahuan siswa yang diperolehnya dari presentasi di kelas dan pelaksanaan kerjaa tim. Game tersebut dimainkan di atas meja dengan tiga orang siswa, yang masing-masing mewakili tim yang berbeda. Kebanyakan game hanya berupa nomor-nomor pertanyaan yang ditulis pada lembar yang sama.seorang siswa mengambil sebuah kartu bernomor dan harus menjawab pertanyaan sesuai nomor yang tertera pada kartu tersebut. Sebuah aturan tentang penantang memperbolehkan para pemain saling menantang jawaban masingmasing.

4) Turnamen

Turnamen adalah sebuah struktur di mana game berlangsung. Biasanya berlangsung pada akhir minggu atau akhir unit, setelah guru memberikan 
presentasi di kelas dan tim telah melaksanakan kerja kelompok terhadap lembarkegiatan. Pada turnamen pertama, guru menunjuk siswa untuk berada pada meja turnamen, tiga siswa berprestasi tinggi sebelumnya pada meja 1, tiga berikutnya pada meja 2, dan seterusnya. Kompetisi yang seimbang ini, seperti halnya sistem skor kemajuan individual dalam STAD, memungkinkan para siswa dari semua tingkat kinerja sebelumnya berkontribusi secara maksimal terhadap skor tim mereka jika mereka melakukan yang terbaik.

\section{5) Team Recognize (Penghargaan Kelompok)}

Tim akan mendapat sertifikat atau bentuk penghargaan yang lain apabila skor rata-rata mereka mencapai kriteria tertentu. Skor tim dapat juga digunakan untuk menentukan dua puluh persen dari peringkat mereka.

c. Langkah-langkah Pembelajaran Teams Games Tournaments (TGT)

1) Guru menyiapkan: kartu soal, lembar kerja siswa, dan alat/bahan.

2) Siswa dibagi atas beberapa kelompok (tiap kelompok anggotanya lima/enam siswa).

3) Guru mengarahkan aturan permainannya.

d. Aturan (skenario)

Dalam satu permainan terdiri dari: kelompok pembaca, kelompok penantang I, kelompok penantang II, dan seterusnya sejumlah kelompok yang ada. Kelompok pembaca, bertugas: (1) ambil kartu bernomor dan cari pertanyaan pada lembar permainan, (2) baca pertanyaan keras-keras, dan (3) beri jawaban. Kelompok penantang kesatu bertugas: Menyetujui pembaca atau memberi jawaban yang berbeda. Sedangkan kelompok peantang kedua: (1) Menyetujui pembaca atau emberi jawaban yang berbeda, dan (2) Cek lembar jawaban.

Kegiatan ini dilakukan secara bergiliran. Gambar Rulersnya dapat dilihat seperti dibawah ini:

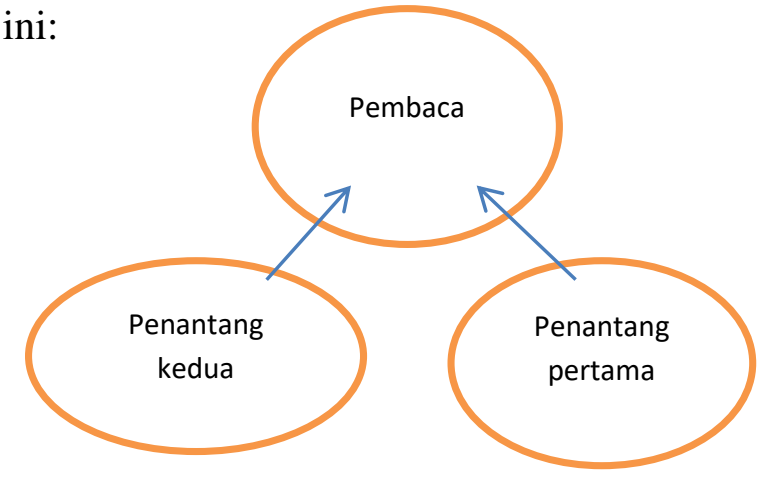

e. Sistem Penghitungan Poin Turnamen

Skor siswa dibandingkan dengan rata-rata skor yang lalu mereka sendiri, dan poin diberikan berdasarkan pada seberapa jauh siswa menyamai atau melampaui prestasi yang dilaluinya sendiri. Poin tiap anggota tim ini dijumlahkan untuk 
mendapatkan skor tim, dan tim yang mencapai kriteria tertentu dapat diberi sertifikat atau ganjaran (award) yang lain.

Adapun kriteria penghargaan yang disarankan adalah sebagai berikut:

\begin{tabular}{l|l}
\hline Kriteria (team average) & Award \\
\hline $30-40$ & Good team \\
\hline $40-45$ & Great team \\
\hline $45-\mathrm{ke}$ atas & Super team \\
\hline
\end{tabular}

f. Kelebihan dan Kekurangan

Metode pembelajran Kooperatif Team Games Tournament (TGT), ini mempunyai kelebihan dan kerkungan. Menurut Suarjana dan Istiqomah, yang merupakan kelebihan dari metode ini adalah:

1) Lebih meningkatkan pencurahan waktu untuk tugas.

2) Mengedepankan penerimaan terhadap perbedaan individu.

3) Dengan waktu yang sedikit dapat menguasai materi secara mendalam.

4) Proses belajar mengajar berlangsung dengan keaktifan dari siswa.

5) Mendidik siswa untuk berlatih bersosialisasi dengan orang lain.

6) Motivasi belajar lebih tinggi.

7) Hasil belajar lebih baik.

8) Meningkatkan kebaikan budi, kepekaan dan toleransi.

Sedangkan kelemahan TGT adalah:

1) Bagi Guru

Sulitnya pengelompokkan siswa yang mempunyai kemampuan heterogen dari segi akademis. Kelemahan ini akan dapat diatasi jika guru yang bertindak sebagai pemegang kendali, teliti dalam menentukan pembagian kelompok.

2) Bagi siswa

Masih adanya siswa berkempuan tinggi kurang terbiasa dan sulit memberikan penjelasan kepada siswa yang lainnya. Untuk mengatasi kelemahan ini, tugas guru adalah membimbing dengan baik siswa yang mempunyai kemampuan akademik tinggi agar dapat dan mampu menularkan pengetahuannya kepada siswa yang lain.

\section{METODE PENELITIAN}

Jenis penelitian yang digunakan oleh peneliti adalah penelitian kuantitatif dengan metode penelitian eksperimen, yang mana peneliti membagi subjek atau objek yang diteliti menjadi dua grup, yaitu grup treatment (yang memperoleh perlakuan), dan grup kontrol yang tidak memperoleh perlakuan, sehingga akan diketahui hubungan kausal tau sebab dan akibatnya. Dalam penelitian ini peneliti menggunakan analisis regresi satu predictor yaitu 
untuk mengetahui hubungan satu variabel (X) yaitu motivasi belajar siswa dengan model pembelajaran Kooperatif TGT, dan satu variabel (Y), yaitu prestasi belajar biologi materi pokok kingdom animalia siswa kelas X MA NU 03 Sunan Katong Kaliwungu Kendal.

Waktu penelitiannya adalah semester genap bulan April 2011. Adapun tempat penelitiannya adalah di MA NU 03 Sunan Katong Kaliwungu Kendal yang beralamat di J1. Sawah Jati Desa Plantaran, Kecamatan Kaliwungu Kabupaten Kendal. Populasi dalam penelitian ini adalah peserta didik MA NU 03 Sunan Katong Kaliwungu Kendal kelas X tahun ajaran 2010/2011, yang terdiri dari kelas XA, XB， X C, dan XD. Namun yang diambil sebagai kelas eksperimen adalah XB, dan kelas kontrolnya XA. Sedangkan sampel dalam penelitian ini diambil secara simple random sampling sehingga didapatkan 3 kelas sebagai sampel penelitian, penentuan kelas uji coba instrumen, kelas kontrol dan eksperimen ditentukan secara acak. Pengambilan sampel dikondisikan dengan pertimbangan bahwa peserta didik mendapatkan materi berdasarkan kurikulum yang sama, peserta didik yang menjadi objek penelitian duduk pada kelas yang sama, dan dalam pembagian kelas tidak ada kelas unggulan. Dalam penelitian ini kelas XB sebagai kelas eksperimen, kelas XA sebagai kelas kontrol.

\section{A. Variabel dan Indikator Penelitian}

Variabel penelitian adalah segala sesuatu yang berbentuk apa saja yang ditetapkan oleh peneliti untuk dipelajari sehingga diperoleh informasi tentang hal tersebut, kemudian ditarik kesimpulannya. Variabel dapat diartikan sebagai obyek pengamatan atau fenomena yang diteliti. Dalam penelitian ini terdapat dua variabel yaitu:

1. Variabel bebas

Variabel bebas adalah variabel yang menjadi sebab timbulnya atau berubahnya variabel terikat. Variabel bebas dalam penelitian ini adalah motivasi belajar peserta didik dengan model pembelajaran Teams-Games-Tournament (TGT), dengan indikator sebagai berikut:

a. Keaktifan Belajar Biologi.

b. Keinginan dan Kemauan Belajar Biologi.

c. Itensitas Belajar Biologi.

2. Variabel terikat

Variabel terikat adalah variabel yang dipengaruhi atau menjadi akibat karena adanya variabel bebas. Variabel terikat dalam penelitian ini adalah prestasi belajar peserta didik pada materi pokok Kingdom Animalia.

\section{B. Teknik Pengumpulan Data}

Teknik pengumpulan data adalah cara yang dapat digunakan oleh peneliti untuk mengumpulkan data. Teknik pengumpulan data dalam penelitian ini dilakukan dengan dua cara:

1. Metode Tes 
Dalam penelitian ini tes digunakan untuk memperoleh data prestasi belajar peserta didik pada materi pokok kingdom animalia. Tes dilakukan dalam bentuk ulangan pada susb bab Kingdom animalia. Bentuk tes yang digunakan berupa tes obyektif (multiple choice) dengan 5 pilihan dan hanya satu pilihan yang benar. Data ini digunakan untuk menjawab permasalahan dalam penelitian. Sebelumnya soal diujicobakan pada kelas uji coba untuk mengetahui validitas, reliabilitas, tingkat kesukaran, dan daya beda item soal.

2. Angket

Metode angket merupakan salah satu cara pengumpulan data yang dilakukan dengan cara memberi seperangkat pertanyaan-pertanyaan tertulis kepada responden untuk dijawab.

\section{Teknik Analisis Data}

1. Analisis Pendahuluan

a. Analisis Angket

Pada analisis ini, data yang telah dikumpulkan dari hasil penelitian yang masih bersifat kualitatif diuraikan secara deskriptif seperti hasil angket tentang keadaan motivasi belajar siswa. Untuk memudahkan data statistiknya maka dibuat lima alternatif jawaban pada setiap item pertanyaan dan diberi skor sebagai berikut :

1) Alternatif jawaban a dengan skor 5 .

2) Alternatif jawaban b dengan skor 4 .

3) Alternatif jawaban c dengan skor 3.

4) Alternatif jawaban d dengan skor 2 .

5) Alternatif jawaban e dengan skor 1.

b. Uji Instrumen Penelitian

Uji instrumen penelitian untuk mengetahui hasil belajar peserta didik berupa tes akan diuji melalui uji validitas dan reliabilitas.

1) Uji validitas

Digunakan untuk menentukan validitas item soal menggunakan rumus korelasi product moment. Dengan taraf signifikan 5\%, apabila dari hasil perhitungan didapat $r_{\text {hitung }} \geq r_{\text {tabel }}$ maka dikatakan butir soal nomor itu telah signifikan atau telah valid. Apabila $r_{h i t u n g}<r_{\text {tabel}}$, maka dikatakan butir soal tersebut tidak signifikan atau tidak valid.

2) Uji reliabilitas

Reliabilitas instrumen adalah ketepatan alat evaluasi dalam mengukur. Suatu tes dapat dikatakan mempunyai taraf kepercayaan tinggi jika tes tersebut dapat memberikan hasil yang tetap. Untuk menghitung reliabilitas tes menggunakan rumus K-R. 20. Kriteria pengujian reliabilitas yaitu setelah didapatkan harga $r^{11}$. instrumen dikatakan reliabel apabila $r^{11}>0,50$. 


\section{3) Tingkat Kesukaran}

Soal yang baik adalah soal yang meliputi aspek kognitif dan tidak terlalu mudah atau terlalu sukar. Soal yang terlalu mudah tidak merangsang peserta didik untuk mempertinggi usaha memecahkannya, sebaliknya soal yang terlalu sukar akan menyebabkan peserta didik menjadi putus asa dan tidak mempunyai semangat untuk mencoba lagi karena di luar jangkauannya.

4) Daya Pembeda Soal

Daya pembeda soal adalah kemampuan untuk membedakan peserta didik yang pandai (berkemampuan tinggi) dengan peserta didik yang kurang pandai (berkemampuan rendah). Dalam penelitian ini untuk mencari daya pembeda dengan menggunakan metode split half, yaitu dengan membagi kelompok yang di tes menjadi dua bagian, kelompok pandai atau kelompok atas dan kelompok kurang pandai atau kelompok bawah.

\section{Analisis Uji Hipotesis}

Analisis ini digunakan untuk menghitung lebih lanjut dengan menguji hipotesis dengan menggunakan analisis regresi linier sederhana. Karena dalam penelitian ini terdapat satu kriterium, yaitu prestasi belajar (Y) dan satu predictor yaitu keadaan motivasi belajar dengan model pembelajaran kooperatif TGT (X).

\section{HASIL DAN PEMBAHASAN}

1. Data Keadaan Motivasi Belajar Peserta didik

a. Kelas Eksperimen (XB)

Untuk memperoleh data tentang Keadaan Motivasi Belajar Siswa Kelas XB Dengan Model Pembelajaran TGT, peneliti menggunakan metode angket, yakni memberikan pertanyaan secara tertulis kepada siswa yang berjumlah 35 siswa dengan 15 item pertanyaan dan dibuat dalam bentuk pilihan ganda. Dengan masing-masing pertanyaan memiliki lima alternatif jawaban, yang masing-masing alternatif jawaban memiliki skor.

Dari tabel distribusi frekuensi dihasilkan nilai sebagai berikut : untuk interval 60-66 dengan nilai 37\%, interval 55-59 dengan nilai 11 interval 50-54 dengan nilai 17\%, interval 45-49 dengan nilai 29\%, interval 40-44 dengan nilai 0\%, dan interval 35-39 dengan nilai 6\%. Dengan demikian bahwa motivasi belajar peserta didik dengan model pembelajaran TGT dapat dikatakan baik, dengan rata-ratanya adalah 53,571 .

b. Kelas Kontrol (XA)

Untuk mengetahui motivasi belajar peserta didik kelas kontrol (XA) yang berjumlah 34 siswa, sama diberikan angket dengan ketentuan yang sama dengan kelas Eksperimen (XB). Dari tabel distribusi frekuensi di atas dihasilkan nilai sebagai berikut : untuk interval 45-47 dengan nilai 9\%, interval 42-44 dengan nilai 8 interval 
39-41 dengan nilai 32\%, interval 36-38 dengan nilai 19\%, interval 33-35 dengan nilai $8 \%$, dan interval 30-32 dengan nilai 22\%. Dari hasil data tersebut dapat diketahui bahwa motivasi belajar peserta didik pada kelas kontrol dikatakan cukup, dengan rata-ratanya adalah 39,058 .

2. Pembahasan Hasil Penelitian

Analisis ini merupakan analisis pengolahan lebih lanjut dari hasil yang telah diperoleh dengan cara membandingkan harga $F_{\text {reg }}$ hitung dengan Ftabel taraf kesalahan $5 \%$ dan $1 \%$, dengan kemungkinan sebagai berikut :

a. Jika $F_{\text {reg }}$ hitung lebih besar daripada $\mathrm{F}$ tabel (5\% dan $\left.1 \%\right)$, maka rumus hipotesis yang menyatakan : ada hubungan yang positif antara motivasi belajar dengan model pembelajaran Kooperatif Teams-Games-Tournament (TGT) dengan prestasi belajar peserta didik mata pelajaran biologi materi pokok kingdom animalia kelas XB (eksperimen) MA NU 03 Sunan Katong Kaliwungu Kendal tahun ajaran 2010/2011 dapat diterima.

b. Jika $F_{\text {reg }}$ hitung lebih kecil daripada $\mathrm{F}$ tabel dengan taraf kepercayaan (5\% dan $1 \%$ ) maka hipotesis peneliti ditolak.

Dari hasil analisis hipotesis diperoleh $F_{\text {reg }}$ hitung sebesar 15,544 dengan derajat kebebasan pembilang $V_{1}=1$ dan penyebut $V_{2}=35$ maka :

$F_{\text {reg }}$ hitung: 15,544> $F_{1} 5 \%(4,13) \quad$ hal ini menunjukan signifikan (hipotesis diterima).

$F_{\text {reg }}$ hitung: $15,544>F_{1} 1 \%(7,44) \quad$ hal ini menunjukkan signifikan (hipotesis diterima)

Dapat dilihat dari rata-rata motivasi belajar dengan penggunaan model pembelajaran TGT lebih besar dari pembelajaran konvensional 53,571>39,056, ini berakibat juga dengan hasil prestasi belajar mata pelajaran biologi materi pokok kingdom animalia kelas eksperimen (XB) rata-ratanya lebih besar daripada kelas kontrol (XA), 73,89>67,65. Dapat dikatakan bahwa penerapan model pembelajaran Kooperatif Teams-Games-Tournament (TGT) dapat meningkatkan motivasi belajar peserta didik dari pada pembelajaran konvensional sehingga berpengaruh dalam meningkatkan prestasi belajar materi kingdom animalia pada peserta didik kelas $\mathrm{X}$ MA NU 03 Sunan Katong Kaliwungu Kendal tahun ajaran 2010/2011. 


\section{SIMPULAN}

Berdasarkan hasil analisis data dan pembahasan yang diperoleh selama penelitian dapat disimpulkan bahwa; terdapat perbedaan yang signifikan antara hasil belajar kognitif peserta didik antara kelas eksperimen yang diberi treatment penerapan model pembelajaran Kooperatif Teams-Games-Tournament (TGT) dengan kelas kontrol dengan pembelajaran konvensional pada mata pelajaran biologi materi pokok Kingdom Animalia (Avertebrata) kelas X di MA NU 03 Sunan Katong Kaliwungu Kendal tahun ajaran 2010/2011, dengan nilai $t_{\text {hitung }}>\mathrm{t}_{\text {tabel }}$ yaitu 3,938> 2,021 (5\%), 3,938>2,704 (1\%). Model pembelajaran Kooperatif Teams-Games-Tournament (TGT) dapat berperan efektif terhadap hasil belajar peserta didik pada mata pelajaran biologi materi pokok filum chordata, dengan rata-rata nilai hasil belajar kognitif kelompok eksperimen adalah 73,89 dan kelompok kontrol adalah 67,65.

\section{DAFTAR PUSTAKA}

Arikunto, Suharsimi. (2007). Dasar-Dasar Evaluasi Pendidikan. Jakarta: Bumi Aksara

Atkinson, J. W, An Introduction to Motivation. (1964). New York: Van Nostrand Reinhold

Dimyati dan Mujiono. Belajar dan Pembelajaran. (2002). Jakarta: Rineka Cipta,

Djaali, Psikologi Pendidikan. (2008). Jakarta: Bumi Aksara,

Gunawan, Adi W. (2004), Genius Learning Strategy “ Petunjuk Praktis Untuk Menerapkan Accelerated Learning”. Jakarta : PT .Gramedia Pustaka Utama

Hadjar, Ibnu, Dasar-Dasar Metodologi Penelitian Kwantitatif dalam Pendidikan, (Jakarta: PT. Raja Grafindo Persada, 1996)

Isjoni. (2009). Pembelajaran Kooperatif Meningkatkan Kecerdasan Komunikasi Antar Peserta Didik, Yogyakarta: Pustaka Pelajar

Mahmud. (2010). Psikologi Pendidikan, Bandung: CV Pustaka Setia

Nasution S. (1995). Didaktik Asas-Asas Mengajar.Jakarta : Bumi Aksara, 1995

Nuryani Y Rustama, dkk.(2003). Startegi Belajar Mengajar Biologi. tt.p : Universitas Pendidikan Indonesia

Sardiman, A. M. (2001). Interaksi dan Motivasi Belajar-Mengajar Cet. Kesembilan, Jakarta: Raja Grafindo Persada, 2001

Slavin, Robert E. (2008). Cooperative Learning: Teori, Riset Dan Praktik, Bandung: Nusa Media 
Sudjana, Nana. (1996). Cara Belajar Siswa Aktif .Bandung: Sinar Baru Algesindo

Sugiyono. (2007). Metode Penelitian Pendidikan Pendidikan Kualitatif, Kuantitatif dan $R$ $\& D$. Bandung : Alfabeta

Sugiyono. (2007). Statistika untuk Penelitian, Bandung: Alfabeta

Suprijono Agus, (2010), COOPERATIVE LEARNING: Teori Dan Aplikasi PAIKEM. Yogyakarta: Pustaka Pelajar

Suryabrata, Sumadi. (2002). Metodologi Penelitian. Jakarta: Rajawali Offset

Trianto. (2010). Mendesain Model Pembelajaran Inovatif-Progresif: Konsep landasan dan Implementasinya Pada Kurikulum Tingkat satuan Pendidikan, Jakarta: Kencana

Uno, Hamzah B. (2008). Teori Motivasi Dan Pengukurannya Analisis Bidang Pendidikan, Edisi 1 Cet. 4, Jakarta: Bumi Aksara

Wayne K. Hoy, and Cecil G. Miskel (1987). EDUCATION ADMINISTRATION Theory, Research, and Practice.New York:Random House 